\title{
REVIEW
}

\section{Current Data on and Clinical Insights into the Treatment of First Episode Nonaffective Psychosis: A Comprehensive Review}

Benedicto Crespo-Facorro · Jose Maria Pelayo-Teran • Jacqueline Mayoral-van Son

Received: May 9, 2016 / Published online: August 23, 2016

(c) The Author(s) 2016. This article is published with open access at Springerlink.com

\section{ABSTRACT}

Implementing the most suitable treatment strategies and making appropriate clinical decisions about individuals with a first episode of psychosis (FEP) is a complex and crucial task, with relevant impact in illness outcome. Treatment approaches in the early stages should go beyond choosing the right antipsychotic drug and should also address tractable factors influencing the risk of relapse. Effectiveness and likely metabolic and endocrine disturbances differ among second-generation antipsychotics (SGAs) and should guide the choice of the first-line

Enhanced content To view enhanced content for this article go to www.medengine.com/Redeem/ 8CE4F06027468BF1.

B. Crespo-Facorro $(\bowtie) \cdot J$. M. Pelayo-Teran . J. Mayoral-van Son

Department of Psychiatry, IDIVAL, School of Medicine, University Hospital Marqués de Valdecilla. CIBERSAM, Centro de Investigación Biomédica en Red de Salud Mental, Edificio IDIVAL, planta 2 | Avda. Cardenal Herrera Oria, s/n. |, 39011 Santander, Spain

e-mail: bcfacorro@humv.es; crespob@unican.es treatment. Clinicians should be aware of the high risk of cardiovascular morbidity and mortality in schizophrenia patients, and therefore monitoring weight and metabolic changes across time is mandatory. Behavioral and counseling interventions might be partly effective in reducing weight gain and metabolic disturbances. Ziprasidone and aripiprazole have been described to be least commonly associated with weight gain or metabolic changes. In addition, some of the SGAs (risperidone, amisulpride, and paliperidone) have been associated with a significant increase of plasma prolactin levels. Overall, in cases of FEP, there should be a clear recommendation of using lower doses of the antipsychotic medication. If no or minimal clinical improvement is found after 2 weeks of treatment, such patients may benefit from a change or augmentation of treatment. Clinicians should provide accurate information to patients and relatives about the high risk of relapse if antipsychotics are discontinued, even if patients have been symptom free and functionally recovered on antipsychotic treatment for a lengthy period of time. 
Keywords: Antipsychotics; Early intervention; Schizophrenia; Treatment

\section{INTRODUCTION}

Schizophrenia is a heterogeneous disorder with a worldwide lifetime prevalence among adults near $1 \%[1,2]$. The illness typically debuts in late adolescence or young adulthood, can affect personal, educational, social, and vocational skills, and ranks among the 20 leading global causes of disability worldwide [3]. Fortunately, and based on recent evidence, the conceptualization of illness outcome has progressively evolved to a more optimistic and inspiring perception of the illness with an expectation of functional recovery from the first episode [4, 5]. Imaging, clinical, and cognitive longitudinal data do not support the notion of a deteriorating course of the illness [6-10], which consequently raises legitimate expectations of living a normal life with mental illness. Systematic reviews of outcome studies have reported that $40-42 \%$ of people with a first episode of psychosis (FEP) have a good outcome [11, 12], although when more stringent criteria of functional recovery are used the rate drops to $13.5 \%$ long term [13].

Schizophrenia is unquestionably a potentially disabling and severe mental illness; however, an appropriate multidisciplinary and integrated treatment approach from the first episode can make a fulfilling and productive life and the achievement of full potential possible in spite of the limitations caused by the illness. "Recent-onset psychosis" has been previously proposed as a more accurate term for referring to individuals who have experienced a short duration of illness (e.g., 2-5 years) [14]. By contrast, the term "first episode psychosis" may include all subjects with a first treatment contact, independently of the duration of the symptoms. It has been stated that there is a critical period of 2-5 years following onset of psychosis during which future trajectories of functional outcome may be set and when interventions are likely to have a maximum beneficial effect [15]. Recovery from a FEP has come into focus as the main goal of any treatment strategy. Many changeable factors such as clinical (medication adherence, treatment response) and psychotherapeutic treatments, psychoeducation about the illness, therapeutic alliance, support and recognition of the needs of the people with a FEP and carers, societal stigma, substance misuse, social and family support, and physical health may affect reaching this functional status [16]. Preventing relapse in the early stages of disease has become a major challenge due to its critical impact on life-long functionality [17]. Non-adherence to antipsychotic treatment and lack of insight into the illness are very frequent in people with a FEP [18]. Poor adherence to treatment is associated with an increased rate of relapse $[19,20]$. Lack of insight promotes non-adherence to medication and leads to a poorer course of illness and functioning [21-23]. Either because clinicians are not always fully aware of these notions or because these ideas are not well understood and accepted by people in the early stages of the illness, achieving and maintaining good adherence to the prescribed treatment is a major clinical issue.

Implementing the most suitable treatment strategies and making appropriate clinical decisions about individuals with a FEP is a complex and crucial task, with associated impact on illness outcome. These beneficial effects seem to be more pronounced for those patients who received the proper comprehensive specialty care as early as 
possible in the course of the illness [24]. Early detection and specialized intervention programs have been extensively implemented in the last decades for both individuals suffering a FEP and their carers, offering a wide range of pharmacological and psychosocial interventions according to their needs. Treatment approaches in the early stages should go beyond choosing the right antipsychotic drug to reduce acute psychotic symptomatology and should also address tractable factors influencing the risk of relapse, with the greatest challenge of accomplishing the long-term goal of functional recovery (to achieve their best premorbid functional level) in most of the individuals with a FEP. These conceptualizations and interventions should also be shared and assumed by clinicians dealing with FEP cases and working in non-specialized mental health clinical settings.

A number of previous publications have reviewed early intervention models or specific issues (i.e., side effects of antipsychotics or long-acting injectable antipsychotics) in the treatment of people with a FEP. However, there is a lack of updated reviews of the pharmacological treatment of people with a FEP, including use of novel antipsychotics that help clinicians to choose and manage these medications. This article aims to provide clinicians with practical recommendations on how best to manage people with a FEP. The selection of an antipsychotic in the first stage of the illness could be a highly relevant decision, with a direct impact on adherence to medication and acceptance of the illness, and therefore influence the course and the outcome of the illness. Advantages and disadvantages of currently widely used drugs to treat schizophrenia are outlined and discussed.

\section{METHODS}

To obtain a fuller picture of the current best treatment of people with a first episode of non-affective psychosis a literature search (1966 up to December 2015), using the MEDLINE database, was conducted for English-language published reviews, meta-analyses, and clinical trials of first generation antipsychotics (FGAs), second generation antipsychotics (SGA), and newly approved antipsychotics. The following keywords were used: first episode psychosis, recent-onset psychosis, schizophrenia, non-affective psychosis, antipsychotics, neuroleptics, effectiveness, and side effects. The review is based upon studies carried out with adults as well as children and adolescents. We attempted to identify additional studies through searches of the reference lists of identified studies and reviews. Relevant data obtained from articles based on chronic schizophrenia samples were clearly identified and separately reported to avoid any misleading literature on first episode subjects.

This article is based on previously conducted studies and does not encompass new studies of human or animal subjects performed by any of the authors.

\section{AIMING FOR EFFICACY AND EFFECTIVENESS}

Balancing risks and benefits of antipsychotic agents and, subsequently, increasing the likelihood of adherence to treatment is the real challenge in the treatment of FEP individuals [25]. Table 1 summarizes the advantages and disadvantages of the antipsychotic agents discussed in this review. The initial better tolerability of SGAs based on the diminished emergence of extrapyramidal 
Table 1 Characteristics and profiles of antipsychotics used in the treatment of people with a first-episode psychosis (FEP)

\begin{tabular}{|c|c|c|c|c|}
\hline Antipsychotic & $\begin{array}{l}\text { Minimum } \\
\text { effective doses } \\
\text { in FEP } \\
(\mathbf{m g} / \text { day })\end{array}$ & Oral/long acting & Advantages & Disadvantages \\
\hline $\begin{array}{l}\text { Haloperidol } \\
\text { and other } \\
\text { FGAs }\end{array}$ & 2 (haloperidol) & $\begin{array}{l}\text { Several agents have } \\
\text { long-acting } \\
\text { injection forms }\end{array}$ & $\begin{array}{l}\text { Overall efficacy in psychotic symptoms } \\
\text { Best level of evidence }\end{array}$ & $\begin{array}{l}\text { High risk of EPS, } \\
\text { cognitive and } \\
\text { depressive symptoms } \\
\text { High risk of } \\
\text { hyperprolactinemia } \\
\text { Lower effectiveness } \\
\text { compared to SGAs } \\
\text { QTc prolongation } \\
\text { (Haloperidol and } \\
\text { other agents) }\end{array}$ \\
\hline Olanzapine & 5 & $\begin{array}{l}\text { Long-acting } \\
\text { injection form } \\
\text { available }\end{array}$ & $\begin{array}{l}\text { High mid- and long-term effectiveness } \\
\text { compared to other antipsychotics } \\
\text { Low risk of hyperprolactinemia }\end{array}$ & $\begin{array}{l}\text { Very high risk of weight } \\
\text { gain } \\
\text { Very high risk of lipid } \\
\text { and glucose } \\
\text { disturbances } \\
\text { Risk of sedation }\end{array}$ \\
\hline Risperidone & 2 & $\begin{array}{l}\text { Oral and long-acting } \\
\text { injection form } \\
\text { available }\end{array}$ & $\begin{array}{l}\text { High mid- and long-term effectiveness } \\
\text { compared to other antipsychotics }\end{array}$ & $\begin{array}{l}\text { Moderate risk of weight } \\
\text { gain and lipid } \\
\text { disturbances } \\
\text { High risk of } \\
\text { hyperprolactinemia } \\
\text { Risk of EPS compared } \\
\text { to other SGAs }\end{array}$ \\
\hline Quetiapine & 150 & Oral & $\begin{array}{l}\text { Efficacy in several symptomatic } \\
\text { domains } \\
\text { Low risk of hyperprolactinemia }\end{array}$ & $\begin{array}{l}\text { Very high risk of weight } \\
\text { gain } \\
\text { Very high risk of lipid } \\
\text { and glucose } \\
\text { disturbances } \\
\text { Sedation } \\
\text { Probably lower } \\
\text { effectiveness } \\
\text { compared to other } \\
\text { SGAs }\end{array}$ \\
\hline
\end{tabular}


Table 1 continued

\begin{tabular}{|c|c|c|c|c|}
\hline Antipsychotic & $\begin{array}{l}\text { Minimum } \\
\text { effective doses } \\
\text { in FEP } \\
(\mathrm{mg} / \text { day })\end{array}$ & Oral/long acting & Advantages & Disadvantages \\
\hline Ziprasidone & 80 & Oral & $\begin{array}{l}\text { Lowest risk of weight gain and neutral } \\
\text { effect on glucose and lipids } \\
\text { Low risk of hyperprolactinemia }\end{array}$ & $\begin{array}{l}\text { Probably lower } \\
\text { effectiveness } \\
\text { compared to other } \\
\text { SGAs } \\
\text { QT prolongation }\end{array}$ \\
\hline Amisulpride & 400 & Oral & Efficacy and effectiveness & $\begin{array}{l}\text { High risk of } \\
\text { hyperprolactinemia } \\
\text { Limited evidence in first } \\
\text { episode psychosis }\end{array}$ \\
\hline Aripiprazol & 10 & $\begin{array}{l}\text { Oral and long-acting } \\
\text { injection form } \\
\text { available }\end{array}$ & $\begin{array}{l}\text { Low risk of weight gain and lipid and } \\
\text { glucose disturbances } \\
\text { Lowest risk of hyperprolactinemia } \\
\text { Low risk of sedation }\end{array}$ & Risk of akathisia \\
\hline Paliperidone & 3 & $\begin{array}{l}\text { Oral and long-acting } \\
\text { injection form } \\
\text { available }\end{array}$ & Low risk of sedation & $\begin{array}{l}\text { Moderate risk of weight } \\
\text { gain and lipid } \\
\text { disturbances } \\
\text { High risk of } \\
\text { hyperprolactinemia } \\
\text { Risk of EPS compared } \\
\text { to other SGAs } \\
\text { Limited evidence in first } \\
\text { episode psychosis }\end{array}$ \\
\hline Clozapine & - & Oral & $\begin{array}{l}\text { Greatest efficacy and effectiveness } \\
\text { Efficacy in people with a FEP that do } \\
\text { not respond to first-line antipsychotic } \\
\text { treatment }\end{array}$ & $\begin{array}{l}\text { Risk of weight gain and } \\
\text { lipid disturbances. } \\
\text { Agranulocytosis and } \\
\text { cardiac risk } \\
\text { Only for resistant } \\
\text { patients }\end{array}$ \\
\hline
\end{tabular}

Other SGA No data available from FEP samples

agents

$F G A$ first generation antipsychotic, $S G A$ second generation antipsychotic, EPS extrapyramidal symptoms

symptoms and tardive dyskinesia has led to the recommendation of SGAs as the first choice for the treatment of a first episode of schizophrenia in almost all international guidelines for early psychosis [26, 27]. Presently it is widely accepted that there is not an obvious 
difference between FGAs and SGAs in terms of efficacy in decreasing the severity of positive symptoms in schizophrenia [26]. However, SGAs have shown higher treatment effectiveness (lower rates of treatment discontinuation) compared to FGAs (findings primarily driven by haloperidol) in people with a FEP [28-31]. This higher discontinuation rate seems to be related not only to extrapyramidal symptoms but also to some other disadvantages of FGAs, as they may produce more secondary negative and cognitive symptoms [32]. Additionally, these negative effects do not seem to be homogeneous among different medications within the SGA group [33, 34].

The response rate to an initial antipsychotic trial is robust and thereafter the likelihood of response decreases notably [35]. It is erroneous to think that all SGAs are equally efficacious and effective [35]. Differences among SGAs in terms of effectiveness have turned out to be a topic of increasing clinical interest, although head-to-head comparisons between the different SGAs are scarce in real-world clinical practice. Crespo-Facorro and colleagues [34, 36, 37] observed that individuals on quetiapine were more likely to discontinue treatment after a first episode due to insufficient efficacy compared to those people treated with aripiprazole and ziprasidone. A higher risk of treatment discontinuation has been associated with quetiapine treatment during the early phases of treatment [18]. Kahn et al. [31] described no difference between quetiapine and ziprasidone in the rate of treatment discontinuation for any cause, although discontinuation because of insufficient efficacy was to some extent higher with quetiapine (40\%) compared with ziprasidone (26\%) recipients at 1 year. Inadequate and transient dopamine D2 receptor occupancy with quetiapine may lead to insufficient antipsychotic efficacy [38, 39].
Additionally, ziprasidone has been reported to be slightly less effective than other antipsychotics in the treatment of people with a first episode of psychosis [40]. In a sponsored investigation, there were no significant differences between olanzapine, risperidone, and quetiapine in clinical efficacy or rate of treatment discontinuation after 1 year [41]. Most of the medium-term randomized studies have shown similar rates of clinical response and all-cause treatment discontinuation in people with a FEP treated with other SGAs (risperidone, olanzapine, ziprasidone, aripiprazole, amisulpride) [28, 31]. Robinson et al. [33] showed a similar efficacy and effectiveness between aripiprazole and risperidone for the acute treatment of first-episode schizophrenia. Olanzapine might lead to longer treatment maintenance than haloperidol or ziprasidone in treatment-naïve people with a FEP [40]. Accordingly, Glick et al. have reported in a metanalysis of medium and long-term effectiveness that olanzapine and risperidone appear to be the most effective antipsychotics in the treatment of schizophrenia and FEP [42].

In accordance with these findings, studies based on samples of people with chronic schizophrenia also pointed out that quetiapine and ziprasidone could be somewhat less effective than some other widely used SGAs. Quetiapine has been shown to be less effective than risperidone (24\% dropouts due to inefficacy in the quetiapine group vs. $19 \%$ in the risperidone group, RR: 1.26$)$ or olanzapine (70\% dropouts due to any reason and $25 \%$ due to inefficacy in quetiapine vs. $57 \%$ and $14 \%$, respectively, in the olanzapine group, RRs 1.22 and 1.8) [43]. When compared to olanzapine, subjects on ziprasidone had a RR of 1.26 of stopping medication due to any reason and of 1.57 of due to medication inefficacy [44] Efficacy and 
effectiveness in chronic schizophrenia does not seem to be significantly different among the rest of the SGAs $[45,46]$.

Differences in effectiveness among SGAs could help clinicians to avoid choosing the lesser efficacious antipsychotics as first line treatment.

\section{CARDIOMETABOLIC SIDE EFFECTS: SILENT LONG-TERM DAMAGE}

In deciding among therapeutic options, clinicians need to be aware of the differential efficacy and safety of each agent. The choice by clinicians of which antipsychotic drug to use for first-line treatment of the illness is widely based on the profile of side effects that may put treatment alliance (at short-term) and physical health (at medium- and long-term) at risk. Drug-naïve subjects are at a higher risk of suffering antipsychotic side effects [47, 48] Appearance of disturbing side effects and concerns over the long-term damage associated with antipsychotics are among the key factors that make individuals discontinue treatment once their acute symptoms have subsided after a first episode of psychosis $[29,49]$. The risk of metabolic and endocrine disturbances differs among SGA drugs.

Clinicians should be aware of the high risk of premature mortality and lower life expectancy in people with schizophrenia, the increase in cardiovascular morbidity and mortality in FEP being a critical factor for this risk status [50]. Therefore, prevention of the development of cardiovascular risk factors (metabolic syndrome and obesity, lifestyle, physical inactivity, and unhealthy diet) from the first manifestation of the illness is crucial in an integrative treatment of psychosis [51]. Cardiovascular risk (weight or metabolic indices), however, seems to be similar in untreated FEP individuals and healthy controls and noticeably increases after first-time antipsychotic treatment [52]. Antipsychotic medication, in particular SGAs, are related to marked weight gain and frequent metabolic side effects, largely in young people during early phases of the illness [53-55].

Weight gain may indirectly give rise to the development of other components of metabolic syndrome, and therefore be associated with distress, lower functional outcome and non-compliance with medication in individuals with chronic schizophrenia [56-58], and thus should ideally be prevented from the first manifestation of the illness. Even so, psychiatrists and patients should keep in mind that cardiometabolic disturbances might emerge without significant weight gain $[59,60]$.

Monitoring likely weight and metabolic changes across time is mandatory in FEP individuals who have just initiated antipsychotic treatment.

\section{Weight Gain}

The first months of antipsychotic treatment represent the critical period for changes in weight $[61,62]$. Longitudinal studies in drug-naïve subjects have shown that the percentage of obese (body mass index (BMI) $>30$ ) subjects increased from $5 \%$ to $32 \%$ and the percentage of overweight rose up to $65 \%$ at 3 years after the initiation of treatment with olanzapine, risperidone, or haloperidol [62]. Marked differences in likely weight gain exist among the different SGAs. Of clinical relevance is the fact that several reviews and studies have shown that olanzapine and clozapine are associated with a greater risk of weight gain and higher percentage of extreme weight gain $(>7 \%)$ and aripiprazole and ziprasidone have a low risk of weight gain $[52,60,63]$. In a recent 
study in drug-naïve individuals with a FEP, aripiprazole and quetiapine showed a significant increase in weight compared to ziprasidone [54]. Studies on drug-naïve subjects are in agreement with this statement, in particular during the first months of treatment [45, 64, 65]. The EUFEST study revealed that ziprasidone has a lesser effect on weight gain than quetiapine and olanzapine $[31,66]$. Low doses of risperidone and aripiprazole show a similar pattern of weight gain during early phases of treatment in people with a FEP [33, 54].

Accordingly, aripiprazole and ziprasidone have shown lower liability for inducing weight gain and metabolic adverse reactions than olanzapine and risperidone in long-term schizophrenia populations [64, 67-69]. Furthermore, several studies have shown that switching from treatments with a high risk of weight gain to ziprasidone $[70,71]$ or to aripiprazole [72] is an effective strategy to reduce weight and improve metabolic outcomes in people with stable chronic schizophrenia or schizoaffective disorder. Finally, short-term, double-blind clinical trials comparing ziprasidone with placebo parameters $[73,74]$ or aripiprazole with placebo [75] in people with chronic schizophrenia or schizoaffective disorder have not found significant differences in their effects on metabolic variables.

The severity of weight increase, and therefore fatty change, is correlated with hepatic and cardiovascular toxicity. Thus, obesity is a risk factor for nonalcoholic fatty liver disease (NAFLD), which is the most common cause of liver disease in Western countries [76]. Overall, it has been described that $50 \%$ of people with a BMI >30 may suffer NAFLD. In a recent study, it has been demonstrated that over $25 \%$ of individuals with a FEP will develop liver steatosis after 3 years of treatment (Morlan et al. 2015 submitted, personal communication). Because of the link between cardiometabolic risk, NAFLD, and antipsychotic medication, early detection in clinical practice of NAFLD development, based on non-invasive techniques, could be worthy of consideration, as these subjects should be considered for liver disease treatment and for monitoring and potential treatment of underlying cardiovascular risk factors [77]. It has been observed that individuals treated with olanzapine who gained a substantial amount of weight manifested significantly lower heart rate variability (a marker of high cardiovascular risk) [78].

In addition to physical disturbances, weight stigmatization and discrimination lead to important psychological stress that increases the risk for depression, low self-esteem, and body dissatisfaction in people with schizophrenia [79]. In the long term, weight gain may lead to poorer social and functional outcomes [80] and weight loss is linked to an improvement in social functioning [81] in people with schizophrenia.

Behavioral and counseling interventions including smoking cessation, dietary measures, and exercise might be partly effective in reducing weight gain and metabolic disturbances in early stages of treatment [82-84]. Nonetheless, the benefits of these lifestyle interventions do not seem to persist across time [85]. The preferential use of or switching to medications with a lower risk of weight and/or metabolic abnormalities is recommended [86].

\section{Glucose Metabolism}

The risk of glucose intolerance and diabetes associated with antipsychotic treatments seems 
to be increased in younger subjects [87]. After 3 years of antipsychotic treatment, insulin plasma levels and the HOMA index tend to increase in FEP individuals [62]. Olanzapine, clozapine, and quetiapine have been associated with more prevalent hyperglycemia independently of body mass in both drug-naïve [88] and chronic schizophrenia individuals [89, 90]. Higher levels of insulin and insulin resistance were associated with olanzapine treatment in patients with FEP or schizophrenia and in healthy normal-weight men $[31,91,92]$. Quetiapine treatment has also been shown to increase the risk of triglycerides to HDL-C ratio (a marker of insulin resistance) in FEP [50]. A critical factor to bear in mind by clinicians is the fact that type 2 diabetes might have an onset a median of 4 years after first antipsychotic treatment, although subjects on olanzapine had a shorter time to diabetes onset [88]. It has also been reported that olanzapine discontinuers did not have an increased risk of diabetes [88]. Higher antipsychotic dosages and male sex seem to be related to an increased risk for diabetes. Due to the close association between metabolic effects and the greater risk of diabetes, pre-diabetes or type 2 diabetes should be prevented or postponed by choosing as a first choice an antipsychotic with a lower cardiometabolic burden.

\section{Lipid Metabolism}

After 3 years of antipsychotic treatment, a high proportion of FEP individuals may have been exposed to high plasma total triglyceride concentrations (up to 23\%), low levels of HDL-C (23\%), and a high total cholesterol/ HDL-C ratio (29\%) [62]. Olanzapine and quetiapine have shown the greatest effect on lipid status, whereas aripiprazole and ziprasidone have produced the lowest effects on lipid levels in both FEP and chronic schizophrenia populations [32, 93]. Our group has described that after 12 weeks of treatment ziprasidone has a neutral effect on fasting plasma lipids and glucose [54]. Importantly, increases in dyslipidemia and triglycerides have been shown to be meaningfully associated with olanzapine treatment independent of weight gain in both FEP and chronic schizophrenia [94, 95]. In a recent study, Robinson and colleagues (2015) observed that cholesterol and LDL-C levels, but not triglycerides and HDL-C, were significantly less affected in individuals on aripiprazole compared to risperidone-treated FEP patients [33].

\section{ADDITIONAL RELEVANT ADVERSE EVENTS}

\section{Prolactin-Related Side Effects}

Hyperprolactinemia is considered to be a disturbing adverse effect of antipsychotic medication, although recent investigations have described that it might be also a pre-existing or stress-related condition, since it has been described in antipsychotic-naïve people with FEP [96-99] and in subjects with an at-risk mental state [96]. Antipsychotic medications differ in their propensity to induce hyperprolactinemia (for a review see Peuskens et al. [100]). Most FGAs have been associated with a pronounced elevation of prolactin levels in the treatment of FEP $[30,101]$, but some investigations in FEP have described no significant prolactin changes at long term associated with haloperidol treatment [31, 98]. Some of the SGAs are considered prolactin-sparing antipsychotics and quetiapine, ziprasidone, olanzapine, clozapine, and aripiprazole are less likely to induce sustained hyperprolactinemia 
[31, 39, 54, 98, 102], but others have been associated with significant increases in plasma prolactin levels, and thus are considered to be prolactin-elevating antipsychotics risperidone, amisulpride, and paliperidone [31, 101]. Nonetheless, clinicians should be fully aware that $40 \%$ of the subjects on prolactin-sparing antipsychotics might exhibit hyperprolactinemia. Plasma prolactin level elevations with antipsychotic drugs are generally dose dependent [100].

Many patients with elevated prolactin levels are asymptomatic, and others may not report symptoms unless specifically questioned [103]. Sustained elevation of prolactin may cause amenorrhea, galactorrhea, hirsutism, gynecomastia, impotence, loss of libido, and infertility in the short term. Long term hypogonadism due to hyperprolactinemia may lead to osteoporosis and hip fracture [100]. The expected utility of switching to or adding aripiprazole to rapidly decrease elevated prolactin levels induced by prolactin-elevating antipsychotics has been described in samples of patients with chronic schizophrenia [104, 105].

Antipsychotic-associated hyperprolactinemia is the most common cause of elevations in prolactin levels in individuals with schizophrenia, but additional appropriate investigations may also be warranted for those individuals with persistently elevated prolactin levels [106]. Clinicians should consider reducing the antipsychotic dosage or switching to an antipsychotic drug with a lower potential to elevate prolactin in cases of hyperprolactinemia.

\section{Sedation}

Sedation is a common and unpleasant adverse effect of both FGAs and SGAs [18], with young subjects seemingly more affected by somnolence and hypersomnia than older adults [107, 108]. Given that sedation-related side effects may particularly cause discomfort and daytime dysfunction, this effect may lead to patients becoming non-adherent to treatment in patients with schizohrenia [109]. Some clinicians may regard sedation as a helpful effect during an acute episode for addressing symptoms such as insomnia and agitation and may use antipsychotics with sedative effects, antipsychotic combinations or higher doses in order to obtain sedation. However, in a phase-specific treatment, sedation may no longer be needed and should be closely monitored and prevented, including the reduction of antipsychotic doses, avoiding polypharmacy, or switching the antipsychotic [110]. Leutch et al. showed evidence that clozapine and chlorpromazine are associated with higher sedation, and amisulpride and paliperidone certainly produce less sedation in the treatment of individuals with schizophrenia [111].

\section{OTHER KEYSTONE ASPECTS IN THE TREATMENT OF FIRST-EPISODE INDIVIDUALS}

\section{What are the Recommended Doses at Early Phases?}

Young people suffering from a first episode of psychosis seem to be highly responsive to low doses of antipsychotics and more susceptible to extrapyramidal side effects and to acute weight gain $[112,113]$. In the last few decades, chlorpromazine doses in people with schizophrenia and other psychoses have been gradually reduced and this has probably led to less extrapyramidal side effects [114]. A clear 
limitation when establishing the lower effective antipsychotic dose in the FEP population is that available dose-equivaleny methods for antipsychotics are not applicable to FEP [115]. Additionally, people with a FEP are more likely to respond to lower doses of antipsychotic medications and treatment should be started at the lower half of the recommended dosage range for multiple episodes (300-500 mg chlorpromazine equivalents per day) [116]. There is a clear recommendation for using lower doses of antipsychotic medications in cases of FEP [27, 116, 117]. Previous studies assessing the efficacy of antipsychotics in FEP have evaluated the efficacy of lower doses. The mean modal doses of risperidone have ranged from 2.4 to $4 \mathrm{mg} /$ day $[41,101,118,119]$, and of olanzapine from 9.1 to $12.6 \mathrm{mg} /$ day $[31,41,120]$. Minimum effective doses of $2 \mathrm{mg}$ of haloperidol [121] or lower and $2 \mathrm{mg}$ of risperidone [120] have been previously reported in FEP. As an example, in our cohort, FEP was effectively treated with initial modal doses at 6 weeks of $5 \mathrm{mg}$ of haloperidol (range 3-9 mg/day), $\quad 4 \mathrm{mg}$ of risperidone (3-6 mg/day), $15 \mathrm{mg}$ of olanzapine (5-20 mg/day) [49], $15 \mathrm{mg}$ of aripiprazole (5-20 mg/day), $\quad 80 \mathrm{mg}$ of ziprasidone (40-160 mg/day), or $300 \mathrm{mg}$ of quetiapine (100-600 mg/day) [36]. In a recent investigation Robinson et al. used mean daily doses of $14.8 \mathrm{mg}$ for aripiprazole and $3.2 \mathrm{mg}$ for risperidone [33]. Even with a "start low, go slow" model, given that people with a FEP require low doses, they may be treated with effective doses from the first week and the antipsychotic rapid titration should allow adjusting doses to avoid side effects.

Although doses may be reasonably increased within the therapeutic range if a clinical response is not obtained, an increase in the antipsychotic dose is less likely to be successful in FEP, so using high antipsychotic doses is discouraged [35].

It has been suggested that the long-term use of antipsychotics may lead to a dopaminergic supersensitivity state, caused by an upregulation of the dopamine receptors [122] that would predispose patients with psychosis who receive longer and higher doses to relapse. However, studies that have tried to test this theory have failed to prove it, as they did not find differences according to medication type withdrawn or tapered [123].

\section{How Long Should Clinicians Wait Before Switching an Initiated Antipsychotic Drug in Cases of Lack of Efficacy?}

According to international treatment guidelines, there is uncertainty about the recommended time clinicians should wait before switching medication, suggesting an initial trial of "appropriate doses" of antipsychotics from 2 to 6 weeks according to current guidelines [124, 125]. The risk-benefit assessment clearly favors switching antipsychotics when a given medication is clearly ineffective. Nevertheless, clinicians, before making the decision to switch, should ensure that treatment with the pre-switch antipsychotic was optimized in terms of adherence and dose [126]. In a recent meta-analysis, Samara et al. reported that people with schizophrenia who did not even minimally improve at week 2 of treatment with sufficiently high doses are unlikely to respond later and therefore may benefit from a change or augmentation of treatment. Ninety percent of subjects who do not show a minimal response (20\% reduction in the PANSS/BPRS score) at the 2-week assessment will not show 
clinical improvement at week 6 [127]. Although the application of these results seems to be more appropriate for people who are not in their first episode of schizophrenia, they emphasize the need for a rapid titration model in order to achieve an adequate dose during the first days of treatment. Additionally, clinicians dealing with FEP individuals should be fully aware of the necessity of switching or implementing augmentation treatment strategies early in the course of the antipsychotic treatment to avoid unnecessary long-term exposure to an antipsychotic that is very unlikely to be helpful. Lack of clinical efficacy is among the reasons that might prompt people with an FEP to treatment discontinuation [19]. Strategies for switching have been previously poorly studied in an attempt to make an accurate recommendation, but the future results of two ongoing trials, SWITCH and OPTiMiSE, should help decision making and provide a basis for clinical guidelines. In a previous finding, Agid et al. [128] described only a $20 \%$ responsiveness among subjects who did not respond to the first-line antipsychotic drug, whereas the efficacy rate of clozapine in these nonresponsive subjects was 75\%; therefore early after a lack of response, a second antipsychotic trial and then the use of clozapine may be indicated when other issues such as adherence or co-morbidity have been addressed [27, 125].

Likely problems in switching antipsychotics in the treatment of schizophrenia such as the risk of discontinuation reactions and the re-emergence of psychotic symptoms have been traditionally described $[129,130]$. Thus, overall patients should be monitored carefully throughout the switch procedure for any discontinuation effects or new side effects
[131, 132]. More frequent contacts might be needed during the switching process in order to reassure the patient and to monitor for side effects and discontinuation problems $[133,134]$.

As with individuals with several episodes, using antipsychotic polypharmacy is discouraged due to a lack of proven efficacy and a higher risk of side effects $[125,135]$. Importantly, co-morbid symptoms such as depression, anxiety, suicide risk, and substance misuse must be correctly diagnosed and treated in order to avoid early refractoriness, lack of remission, and relapse $[27,125]$. Subjects who not respond to the first antipsychotic trial after a few weeks have a low response rate thereafter. Addressing co-morbidity must include not only choosing the appropriate antipsychotic medication but also offering adequate psychosocial interventions such as cognitive behavior therapy (CBT) or treating associated problems such as substance abuse [136, 137]. CBT has been reported as a useful treatment for schizophrenia in several reviews [138-141], particularly in the treatment of persistent positive symptoms as part of a combined therapy. This has led to the inclusion of CBT into services and recommendations of treatment guidelines for people suffering psychotic disorders, including a FEP [27, 125]. Moreover, CBT seems to be helpful in improving other symptoms such as negative symptoms, functioning, mood, and social anxiety [142-145]. However, Jauhar et al. described in a meta-analysis of CBT effectiveness for symptoms of schizophrenia that pooled effect sizes were in the "small" range for all the classes of symptoms considered (pooled effect size of -0.33 for overall symptoms; -0.25 for positive symptoms; 
negative sign favors CBT) [146]. Previous recent meta-analyses by Wykes et al. had described higher levels of effectiveness that were in any case modest (i.e., pooled effect size of -0.37 for positive symptoms, pooled effect size of -0.44 for negative symptoms) [147]. With regard to substance misuse, integrated CBT and motivational interviewing have been used with the aim of reducing the use of substances and reduce subsequent relapses in a FEP; however, results of these interventions are not clearly consistent [137, 148-150]. Although there are some ongoing trials evaluating the specific efficacy of CBT and motivational interviewing in reducing the use of some substances such as cannabis [151], it is possible that the benefits of these psychosocial interventions are best reflected in their effects on symptomatic outcomes rather than in a reduction of substance use or relapse prevention, and therefore the appropriate strategy may be to address associated problems rather than the substance use per se [137]. CBT for psychosis (CBTp) cannot be considered as a global brand because not all approaches are the same. It is now highly recommended that choosing the most appropriate CBTp should take into account patient-defined goals and critical targets and the types of individuals who can benefit from therapy [152].

\section{How Long Should Patients be Maintained on Antipsychotic Medication After Recovering from a First Episode?}

In clinical practice, due to the lack of insight into the prophylactic effects of drugs, emergence of disturbing side effects, and concerns over the long-term harm associated with antipsychotics, it is unlikely that patients will accept an indefinite treatment after a single episode of psychosis [20]. However, stopping antipsychotic medication has been repeatedly demonstrated as the biggest predictor of relapse after a first episode [153-155]. Wunderink et al. [156], exploring people that remitted after a FEP, observed that relapse rates were two times higher in individuals who gradually tapered or discontinued medication and only $20 \%$ of subjects could be successfully discontinued. Strikingly, those patients with an earlier reduction or discontinuation treatment strategy appear to have long-term functional gains compared with individuals who maintained treatment $[157,158]$. In a recent investigation, Mayoral-van Son et al. [20] described a high risk of symptom recurrence after antipsychotic treatment discontinuation in individuals who had accomplished a functional recovery after a single psychotic episode. Moreover, those relapsed individuals had a greater severity of symptoms and lower functional status after 3 years. The profile of individuals who would benefit from treatment discontinuation, and the optimal duration of prophylactic antipsychotic medication remain unclear. The lowest effective-dose regimen is highly recommended $[20,154]$ and a trial off antipsychotic medication is not to be recommended [159]. Clinicians should provide accurate information to people with a FEP (and relatives) about the fact that even if they have been symptom free and functionally recovered on antipsychotic treatment, the risk of relapse is still likely to be high if antipsychotics are discontinued [160]. Despite these clear statements, numerous individuals may still be disposed to discontinue medication after recovering from their single episode of psychosis and, therefore, a planned medication withdrawal strategy with a systematic follow-up should be established in first-episode programs to prevent unrestrained treatment discontinuation. 


\section{What Else Can Clinicians do to Increase Treatment Adherence during Early Phases of the Illness?}

Independent of the initial high response rate after a FEP, during follow-up of the illness, the relapse rates are high, being up to $83 \% 5$ years after the FEP [153]. Persistent substance use disorder, carer criticism, poorer premorbid adjustment, and, particularly, medication nonadherence (a fourfold risk) may significantly increase the risk for relapse in FEP [161]. In a previous report analyzing a subsample of 140 first episode individuals, we observed a similar relapse rate of $65 \%$ at 3 years after the first break of the illness, being adherence to antipsychotic treatment the only significant predictor for relapse [155]. Therefore, in order to prevent relapse, the best way would be to improve adherence and to reduce other avoidable risk factors such as substance use or carer criticism. A basic strategy that may help clinicians improve their patients' adherence includes improving prescriber-patient communication. The clinician should listen the patient, understand his or her perspective, beliefs and concerns about the illness and treatment, and should provide information regarding potential effectiveness, side effects, and formulations in order to get the patient involved in decisions about their medications [162]. The use of psychosocial treatments, including psychoeducational interventions, CBT, and individual and family interventions, may specifically improve adherence and must be offered in combination with antipsychotic treatment in order to prevent relapses in patients with a FEP [163]. Finally, after the evaluation of adherence and associated risks and the provision of adequate medication, psychoeducation and long-acting injectable (LAI) antipsychotics should be offered in order to improve outcome in selected subjects $[164,165]$. The use of LAI antipsychotics has been traditionally restricted to people who are noncompliant and who have a history of multiple relapses, and FEP is rarely treated with depot medications [166]. Early introduction of LAI therapy in FEP has been associated with a short-term adherence benefit [167]. However, subsequent follow-up of the same cohort did not reveal differences between patients treated with LAI therapy and patients with oral antipsychotics in time to initial non-adherence at 104 weeks [168]. Although more well designed, randomized, controlled clinical trials using SGA LAIs exploring effectiveness and likely long-term side effects are warranted, LAIs should be given due consideration in early phases treatment of based on their benefits with regard to adherence [169]. In a recent review of the literature on the use of LAIs in first-episode and early schizophrenia, Taylor and $\mathrm{Ng}$ concluded that LAIs are useful in reducing symptom severity and the risk of relapse, particularly if they voluntary accept LAI therapy [170]. Ironically, clinicians are often reluctant to offer LAIs in early phases and tend to overestimate potential objections by patients [171].

After obtaining a clinical response, accomplishing symptomatic and functional remission is one of the major objectives of treating individuals with a FEP, with a final objective of functional recovery. In 2005, the Remission in Schizophrenia Working Group published the most widely accepted criteria to define remission in schizophrenia [172]. This concept includes the remission of positive psychotic, disorganized, and negative symptoms to a severity of mild or less, but also a minimum duration time for this remission of 6 months, and has been used in 
FEP. Rates of remission vary widely in different studies and most of them do not provide duration criteria [173]. As an example, after a 1 -year follow-up, only $31 \%$ of the initial subjects enrolled in the PAFIP program achieved remission [174], in particular due to persistence of negative symptoms or to relapse in the last 6 months, which seem to be related to duration of untreated psychosis and premorbid functioning. Remission is closely related to functional recovery, although symptomatic remission rates tend to exceed functional recovery rates [173]. The best ways to achieve remission after improving initial symptoms seem to be preventing relapses and also detecting and treating secondary negative symptoms as early as possible. Additionally, vocational interventions have been recognized to be beneficial to achieve better functional outcomes [175].

\section{What Can we do to Help and Support Families and Caregivers of Individuals Dealing with a First Episode?}

One of the main objectives of FEP programs and early intervention services is to engage with both people with psychosis and their family and to facilitate support. However, until recently, most of the effort has gone into studying, recognizing, and reducing expressed emotion (EE) and its components - critical comments (CC) and emotional over-involvement (EOI) due to its potential prediction of relapse and symptom exacerbation in schizophrenia. Given that a large majority of people during their FEP live at home with their families, these informal caregivers are affected by a stress-appraisal-coping framework [176]. This would mean that the extent to which the stressors are related to the relative's or caregiver's negative health is related to his/her appraisal (or subjective evaluation) of the stressor and his/her ability to cope with them. Apart from family interventions, basically aimed at preventing or reducing relapses, psychoeducation and support groups have been developed to improve the experience of caring for people with mental illness, and particularly may be recommended to families and caregivers of people with FEP and severe mental disorders [177]. The role of FEP programs and early intervention services is to detect the needs of the families and caregivers and give sustained appropriate communication and support, in order to improve their experience of caring and reduce associated stress.

\section{New Second Generation Antipsychotics: Future Options for First-episode Treatment}

Although the antidopaminergic mechanism (need for D2R blockade) is still essential in the development of new antipsychotics, the investigation of new atypical antipsychotics has focused on either compounds with a broader spectrum of clinical benefits through dual dopaminergic and serotoninergic properties - "serotonin-dopamine activity modulators"- (e.g., partial agonism of D2R with enhanced affinity for specific serotonin receptor analog of aripiprazole) or exploiting less examined mechanisms (e.g., cholinergic, histaminergic, GABAergic, modulation of glutamate); for a review see Zajdel et al. [178]. Brexpiprazole, with structure, properties and uses that are most similar to those of aripiprazole, has recently exhibited good tolerability, with a lower incidence of akathisia than aripiprazole [179]. Initial animal studies with cariprazine, a potent D3/D2 receptor partial agonist with favored binding to D3 
receptors, seem to point out it could be a better treatment option for patients with persistent and predominant negative symptoms [180]. The long half-life of cariprazine's principal active metabolites and the steady-state levels of cariprazine and metabolites within 4 weeks are pharmacological characteristics that may minimize the impact of missing doses on plasma levels [181]. Significant improvement in hostility has been also observed in cariprazine- versus placebo-treated patients [182]. Iloperidone shares a high affinity for both D2 and 5HT2A receptors, with a unique receptor-binding profile that includes a very strong affinity for the noradrenergic alpha 1 (NEa1) receptor [183]. It is a well-tolerated antipsychotic with a very low propensity to cause either akathisia or antipsychotic-induced extrapyramidal symptoms [184]. Lurasidone exerts a potent antagonism toward the dopamine D2, and the 5-hydroxytryptamine (5-HT, serotonin) receptors: 5-HT2A and 5-HT7 [185]. Apparently lurasidone is less efficacious than clozapine, risperidone, paliperidone, olanzapine, and amisulpride, with a lower risk of sedation and body mass increase [111, 186]. However, subjects treated with lurasidone exhibited higher rates of akathisia, parkinsonism, and hyperprolactinemia compared to several other atypical antipsychotics. To the best of our knowledge none of the above new SGAs have been studied in first-episode cohorts to date.

\section{CONCLUSION}

Treating individuals with a FEP is a complex and crucial task, with important impact on illness outcome. The selection of antipsychotic at the first episode of the illness is an important decision, with a direct impact on adherence to medication and acceptance of the illness, and therefore influencing the course and the outcome of the illness. It is erroneous to think that all SGAs are equal in terms of effectiveness and risk of side effects. Clinicians need to be aware of the potential efficacy and safety of each antipsychotic in order to choose the most appropriate drug for the needs of individual patients. Monitoring likely weight and metabolic changes across time is mandatory in individuals who have just initiated antipsychotic treatment. Intervention strategies in early stages should certainly go beyond choosing the proper antipsychotic and should also tackle tractable factors influencing adherence to treatment and risk of relapse, with the aim of accomplishing the long-term goal of functional recovery. Clinicians should provide accurate information to patients with a FEP and their relatives about the risk of relapse if antipsychotics are discontinued, and assess the needs of the families and caregivers in giving support in order to improve their experience of caring and reduce associated stress.

\section{ACKNOWLEDGMENTS}

We wish to thank the PAFIP researchers who have carried out a great number of outstanding investigations that have notably contributed to improving our knowledge in the field of early psychosis treatment. We would also like to thank the participants and their families for enrolling in these studies.

This review was carried out at the Hospital Marqués de Valdecilla, University of Cantabria, Santander, Spain, with the following Grant support: Instituto de Salud Carlos III PI020499, PI050427, PI060507, Plan Nacional de Drugs Research Grant 2005-Orden sco/3246/2004, SENY Fundació Research Grant CI 
2005-0308007, Fundación Marqués de Valdecilla API07/011 and CIBERSAM.

All named authors meet the International Committee of Medical Journal Editors (ICMJE) criteria for authorship for this manuscript, take responsibility for the integrity of the work as a whole, and have given final approval for the version to be published.

Funding. No funding or sponsorship was received for this study or publication of this article.

Disclosures. Prof. Benedicto Crespo-Facorro has received honoraria for consulting/advisory boards from Otsuka Pharmaceuticals and lecture honoraria from Janssen Johnson \& Johnson, Lundbeck, Roche and Otsuka Pharmaceuticals. Dr. José María Pelayo-Terán has received lecture honoraria and travel support form Janssen Johnson \& Johnson, Lundbeck, Otsuka Pharmaceuticals, GlaxoSmithkline and EiLilly. Dr. Mayoral-van Son reports no additional financial support.

Compliance with Ethics Guidelines. This article is based on previously conducted studies and does not involve any new studies of human or animal subjects performed by any of the authors.

Open Access. This article is distributed under the terms of the Creative Commons Attribution-NonCommercial 4.0 International License (http://creativecommons.org/licenses/ by-nc/4.0/), which permits any noncommercial use, distribution, and reproduction in any medium, provided you give appropriate credit to the original author(s) and the source, provide a link to the Creative Commons license, and indicate if changes were made.

\section{REFERENCES}

1. Insel TR. Rethinking schizophrenia. Nature. 2010;468:187-93.

2. Schultz SK, Andreasen NC. Schizophrenia. Lancet. 1999;353:1425-30.

3. Salomon JA, Vos T, Hogan DR, Gagnon M, Naghavi M, Mokdad A, et al. Common values in assessing health outcomes from disease and injury: disability weights measurement study for the Global Burden of Disease Study 2010. Lancet. 2012;380:2129-43.

4. Frese FJ, Knight EL, Saks E. Recovery from schizophrenia: with views of psychiatrists, psychologists, and others diagnosed with this disorder. Schizophr Bull. 2009;35:370-80.

5. Zipursky RB, Reilly TJ, Murray RM. The myth of schizophrenia as a progressive brain disease. Schizophr Bull. 2013;39:1363-72.

6. DeLisi LE. The concept of progressive brain change in schizophrenia: implications for understanding schizophrenia. Schizophr Bull. 2007;34:312-21.

7. Revier CJ, Reininghaus U, Dutta R, Fearon P, Murray RM, Doody GA, et al. Ten-year outcomes of first-episode psychoses in the MRC ÆSOP-10 study. J Nerv Ment Dis [Internet]. 2015;203:379-86.

8. Ayesa-Arriola R, Rodríguez-SánchezJM, Pérez-Iglesias R, Roiz-Santiáñez R, Martínez-García O, Sánchez-Moreno $\mathrm{J}$, et al. Long-term (3-year) neurocognitive effectiveness of antipsychotic medications in first-episode non-affective psychosis: a randomized comparison of haloperidol, olanzapine, and risperidone. Psychopharmacology. 2013;227:615-25.

9. Roiz-Santiáñez R, Ayesa-Arriola R, Tordesillas-Gutiérrez D, Ortiz-García de la Foz V, Pérez-Iglesias R, Pazos A, et al. Three-year longitudinal population-based volumetric MRI study in first-episode schizophrenia spectrum patients. Psychol Med. 2014;44:1591-604.

10. Rodríguez-Sánchez JM, Ayesa-Arriola R, Pérez-Iglesias R, Periañez JA, Martinez-Garcia O, Gomez-Ruiz E, et al. Course of cognitive deficits in first episode of non-affective psychosis: a 3-year follow-up study. Schizophr Res. 2013;150:121-8.

11. Karson C, Duffy RA, Eramo A, Nylander A-G, Offord SJ. Long-term outcomes of antipsychotic treatment in patients with first-episode schizophrenia: a systematic review. Neuropsychiatr Dis Treat. 2016;12:57-67. 
12. Menezes NM, Arenovich T, Zipursky RB. A systematic review of longitudinal outcome studies of first-episode psychosis. Psychol Med. 2006;36:1349-62.

13. Jääskeläinen $E$, Juola $P$, Hirvonen $N$, McGrath JJ, Saha S, Isohanni $\mathrm{M}$, et al. A systematic review and meta-analysis of recovery in schizophrenia. Schizophr Bull. 2013;39:1296-306.

14. Breitborde NJK, Srihari VH, Woods SW. Review of the operational definition for first-episode psychosis. Early Interv Psychiatry. 2009;3:259-65.

15. Birchwood M, Todd P, Jackson C. Early intervention in psychosis. The critical period hypothesis. Br J Psychiatry Suppl. 1998;172:53-9.

16. Jordan G, Lutgens D, Joober R, Lepage M, Iyer SN, Malla A. The relative contribution of cognition and symptomatic remission to functional outcome following treatment of a first episode of psychosis. J Clin Psychiatry. 2014;75:e566-72.

17. Weiden PJ, Olfson M. Cost of relapse in schizophrenia. Schizophr Bull. 1995;21:419-29.

18. Abdel-Baki A, Ouellet-Plamondon C, Malla A. Pharmacotherapy challenges in patients with first-episode psychosis. J Affect Disord. 2012;138:S3-14.

19. Perkins DO, Gu H, Weiden PJ, McEvoy JP, Hamer RM, Lieberman JA. Predictors of treatment discontinuation and medication nonadherence in patients recovering from a first episode of schizophrenia, schizophreniform disorder, or schizoaffective disorder: a randomized, double-blind, flexible-dose, multicenter study. J Clin Psychiatry. 2008;69:106-13.

20. Mayoral-van Son J, de la Foz VO-G, Martinez-Garcia O, Moreno T, Parrilla-Escobar M, Valdizan EM, et al. Clinical outcome after antipsychotic treatment discontinuation in functionally recovered first-episode nonaffective psychosis individuals: a 3-year naturalistic follow-up study. J Clin Psychiatry. 2016;77:492-500.

21. Wiffen BDR, Rabinowitz J, Fleischhacker WW, David AS. Insight: demographic differences and associations with one-year outcome in schizophrenia and schizoaffective disorder. Clin Schizophr Relat Psychoses. 2010;4:169-75.

22. Ayesa-Arriola R, Rodríguez-Sánchez JM, Morelli C, Pelayo-Terán JM, Pérez-Iglesias R, Mata I, et al. Insight dimensions in first-episode psychosis patients: clinical, cognitive, pre-morbid and socio-demographic correlates. Early Interv Psychiatry. 2011;5:140-9.
23. Ayesa-Arriola R, Moríñigo JDL, David AS, Pérez-Iglesias R, Rodríguez-Sánchez JM, Crespo-Facorro B. Lack of insight 3 years after first-episode psychosis: an unchangeable illness trait determined from first presentation? Schizophr Res. 2014;157:271-7.

24. Kane JM, Robinson DG, Schooler NR, Mueser KT, Penn DL, Rosenheck RA, et al. Comprehensive versus usual community care for first-episode psychosis: 2-year outcomes from the NIMH RAISE early treatment program. Am J Psychiatry. 2016;173:362-72.

25. Crespo-Facorro B, Pérez-Iglesias R, González-Blanch C, Mata I. Treatment of the first episode of schizophrenia: an update on pharmacologic and psychological interventions. Curr Psychiatry Rep. 2008;10:202-9.

26. Moore TA, Buchanan RW, Buckley PF, Chiles JA, Conley RR, Crismon ML, et al. The Texas Medication Algorithm Project antipsychotic algorithm for schizophrenia: 2006 update. J Clin Psychiatry. 2007;68:1751-62.

27. International Early Psychosis Association Writing Group. International clinical practice guidelines for early psychosis. Br J Psychiatry Suppl [Internet]. 2005;48:s120-4.

28. Crespo-Facorro B, Pérez-Iglesias R, Mata I, Ramirez-Bonilla M, Martínez-Garcia O, Pardo-Garcia G, et al. Effectiveness of haloperidol, risperidone and olanzapine in the treatment of first-episode non-affective psychosis: results of a randomized, flexible-dose, open-label 1-year follow-up comparison. J Psychopharmacol. 2011;25:744-54.

29. Crespo-Facorro B, Pérez-Iglesias R, Mata I, Martínez-Garcia O, Ortiz V, Pelayo-Terán JM, et al. Long-term (3-year) effectiveness of haloperidol, risperidone and olanzapine: results of a randomized, flexible-dose, open-label comparison in first-episode nonaffective psychosis. Psychopharmacology. 2012;219:225-33.

30. Green AI, Lieberman JA, Hamer RM, Glick ID, Gur $\mathrm{RE}$, Kahn RS, et al. Olanzapine and haloperidol in first episode psychosis: two-year data. Schizophr Res. 2006;86:234-43.

31. Kahn RS, Fleischhacker WW, Boter H, Davidson M, Vergouwe Y, Keet IPM, et al. Effectiveness of antipsychotic drugs in first-episode schizophrenia and schizophreniform disorder: an open randomised clinical trial. Lancet. 2008;371:1085-97.

32. Zhang J-P, Gallego JA, Robinson DG, Malhotra AK, Kane JM, Correll CU. Efficacy and safety of 
individual second-generation vs. first-generation antipsychotics in first-episode psychosis: a systematic review and meta-analysis. Int $\mathrm{J}$ Neuropsychopharmacol. 2013;16:1205-18.

33. Robinson DG, Gallego JA, John M, Petrides G, Hassoun Y, Zhang J-P, et al. A randomized comparison of aripiprazole and risperidone for the acute treatment of first-episode schizophrenia and related disorders: 3-month outcomes. Schizophr Bull. 2015;41:1227-36.

34. Crespo-Facorro B, de la Foz VO-G, Mata I, Ayesa-Arriola R, Suarez-Pinilla P, Valdizan EM, et al. Treatment of first-episode non-affective psychosis: a randomized comparison of aripiprazole, quetiapine and ziprasidone over 1 year. Psychopharmacology. 2014;231:357-66.

35. Agid O, Schulze L, Arenovich T, Sajeev G, McDonald K, Foussias G, et al. Antipsychotic response in first-episode schizophrenia: efficacy of high doses and switching. Eur Neuropsychopharmacol. 2013;23:1017-22.

36. Crespo-Facorro B, Ortiz-García de la Foz V, Mata I, Ayesa-Arriola R, Suarez-Pinilla P, Valdizan EM, et al. Aripiprazole, ziprasidone and quetiapine in the treatment of first-episode nonaffective psychosis: a 12-week randomized, flexible-dose, open-label trial. Schizophr Res. 2013;147:375-82.

37. Crespo-Facorro B, Pérez-Iglesias R, Mata I, Ortiz-Garcia de la Foz V, Martínez-Garcia O, Valdizan EM, et al. Aripiprazole, ziprasidone, and quetiapine in the treatment of first-episode nonaffective psychosis: results of a 6-week, randomized, flexible-dose, open-label comparison. J Clin Psychopharmacol. 2013;33:215-20.

38. Sparshatt A, Taylor D, Patel MX, Kapur S. Relationship between daily dose, plasma concentrations, dopamine receptor occupancy, and clinical response to quetiapine: a review. J Clin Psychiatry. 2011;72:1108-23.

39. Tauscher-Wisniewski S, Kapur S, Tauscher J, Jones C, Daskalakis ZJ, Papatheodorou G, et al. Quetiapine: an effective antipsychotic in first-episode schizophrenia despite only transiently high dopamine-2 receptor blockade. J Clin Psychiatry. 2002;63:992-7.

40. San L, Arranz B, Perez V, Safont G, Corripio I, Ramirez N, et al. One-year, randomized, open trial comparing olanzapine, quetiapine, risperidone and ziprasidone effectiveness in antipsychotic-naive patients with a first-episode psychosis. Psychiatry Res. 2012;200:693-701.

41. McEvoy JP, Lieberman JA, Perkins DO, Hamer RM, $\mathrm{Gu} \mathrm{H}$, Lazarus A, et al. Efficacy and tolerability of olanzapine, quetiapine, and risperidone in the treatment of early psychosis: a randomized, double-blind 52-week comparison. Am J Psychiatry. 2007;164:1050-60.

42. Glick ID, Correll CU, Altamura AC, Marder SR, Csernansky JG, Weiden PJ, et al. Mid-term and long-term efficacy and effectiveness of antipsychotic medications for schizophrenia: a data-driven, personalized clinical approach. J Clin Psychiatry. 2011;72:1616-27.

43. Komossa K, Rummel-Kluge C, Schmid F, Hunger $\mathrm{H}$, Schwarz S, Srisurapanont M, et al. Quetiapine versus other atypical antipsychotics for schizophrenia. Cochrane Database Syst Rev. 2010; CD006625.

44. Komossa K, Rummel-Kluge C, Hunger H, Schwarz S, Bhoopathi PSS, Kissling W, et al. Ziprasidone versus other atypical antipsychotics for schizophrenia. Cochrane Database Syst Rev. 2009; CD006627.

45. Johnsen E, Jørgensen HA. Effectiveness of second generation antipsychotics: a systematic review of randomized trials. BMC Psychiatry. 2008;8:31.

46. Leucht S, Arbter D, Engel RR, Kissling W, Davis JM. How effective are second-generation antipsychotic drugs? A meta-analysis of placebo-controlled trials. Mol Psychiatry. 2009;14:429-47.

47. Robinson DG, Woerner MG, Delman HM, Kane JM. Pharmacological treatments for first-episode schizophrenia. Schizophr Bull. 2005;31:705-22.

48. Tarricone I, Ferrari Gozzi B, Serretti A, Grieco D, Berardi D. Weight gain in antipsychotic-naive patients: a review and meta-analysis. Psychol Med. 2010;40:187-200.

49. Crespo-Facorro B, Pérez-Iglesias R, Ramirez-Bonilla M, Martínez-García O, Llorca J, Luis Vázquez-Barquero J, et al. A practical clinical trial comparing haloperidol, risperidone, and olanzapine for the acute treatment of first-episode nonaffective psychosis. J Clin Psychiatry. 2006;67:1511-21.

50. Correll CU, Robinson DG, Schooler NR, Brunette MF, Mueser KT, Rosenheck RA, et al. Cardiometabolic risk in patients with first-episode schizophrenia spectrum disorders: baseline results from the RAISE-ETP study. JAMA Psychiatry. 2014;71:1350-63.

51. Ringen PA, Engh JA, Birkenaes AB, Dieset I, Andreassen OA. Increased mortality in schizophrenia due to cardiovascular disease-a non-systematic review of epidemiology, possible causes, and interventions. Front Psychiatry. 2014;5:137. 
52. Foley DL, Morley KI. Systematic review of early cardiometabolic outcomes of the first treated episode of psychosis. Arch Gen Psychiatry. 2011;68:609-16.

53. De Hert M, Schreurs V, Sweers K, Van Eyck D, Hanssens L, Sinko S, et al. Typical and atypical antipsychotics differentially affect long-term incidence rates of the metabolic syndrome in first-episode patients with schizophrenia: a retrospective chart review. Schizophr Res [Internet]. 2008;101:295-303.

54. Pérez-Iglesias R, Ortiz-Garcia de la Foz V, Martínez García O, Amado JA, Garcia-Unzueta MT, Ayesa-Arriola R, et al. Comparison of metabolic effects of aripiprazole, quetiapine and ziprasidone after 12 weeks of treatment in first treated episode of psychosis. Schizophr Res. 2014;159:90-4.

55. Newcomer JW. Second-generation (atypical) antipsychotics and metabolic effects: a comprehensive literature review. CNS Drugs. 2005;19(Suppl 1):1-93.

56. Fakhoury WK, Wright D, Wallace M. Prevalence and extent of distress of adverse effects of antipsychotics among callers to a UK National Mental Health Helpline. Int Clin Psychopharmacol. 2001;16:153-62.

57. Vancampfort D, Sweers K, Probst M, Maurissen K, Knapen J, Minguet $\mathrm{P}$, et al. Association of the metabolic syndrome with physical activity performance in patients with schizophrenia. Diabetes Metab. 2011;37:318-23.

58. Weiden PJ, Mackell JA, McDonnell DD. Obesity as a risk factor for antipsychotic noncompliance. Schizophr Res. 2004;66:51-7.

59. Ballon JS, Pajvani U, Freyberg Z, Leibel RL, Lieberman JA. Molecular pathophysiology of metabolic effects of antipsychotic medications. Trends Endocrinol Metab. 2014;25:593-600.

60. Stahl SM, Mignon L, Meyer JM. Which comes first: atypical antipsychotic treatment or cardiometabolic risk? Acta Psychiatr Scand. 2009;119:171-9.

61. Strassnig M, Miewald J, Keshavan M, Ganguli R. Weight gain in newly diagnosed first-episode psychosis patients and healthy comparisons: one-year analysis. Schizophr Res. 2007;93:90-8.

62. Pérez-Iglesias R, Martínez-García O, Pardo-Garcia G, Amado JA, Garcia-Unzueta MT, Tabares-Seisdedos $\mathrm{R}$, et al. Course of weight gain and metabolic abnormalities in first treated episode of psychosis: the first year is a critical period for development of cardiovascular risk factors. Int J Neuropsychopharmacol. 2014;17:41-51.
63. Perez-Iglesias R, Crespo-Facorro B, Amado JA, Garcia-Unzueta MT, Ramirez-Bonilla ML, Gonzalez-Blanch C, et al. A 12-week randomized clinical trial to evaluate metabolic changes in drug-naive, first-episode psychosis patients treated with haloperidol, olanzapine, or risperidone. J Clin Psychiatry. 2007;68:1733-40.

64. Sikich L, Frazier JA, McClellan J, Findling RL, Vitiello B, Ritz L, et al. Double-blind comparison of first- and second-generation antipsychotics in early-onset schizophrenia and schizo-affective disorder: findings from the treatment of early-onset schizophrenia spectrum disorders (TEOSS) study. Am J Psychiatry. 2008;165:1420-31.

65. Arterburn D, Wood GC, Theis MK, Westbrook EO, Anau J, Rukstalis $M$, et al. Antipsychotic medications and extreme weight gain in two health systems. Obes Res Clin Pract. 2015;10:408-23.

66. Boter H, Peuskens J, Libiger J, Fleischhacker WW, Davidson M, Galderisi S, et al. Effectiveness of antipsychotics in first-episode schizophrenia and schizophreniform disorder on response and remission: an open randomized clinical trial (EUFEST). Schizophr Res. 2009;115:97-103.

67. Breier AF, Malhotra AK, Su TP, Pinals DA, Elman I, Adler CM, et al. Clozapine and risperidone in chronic schizophrenia: effects on symptoms, parkinsonian side effects, and neuroendocrine response. Am J Psychiatry. 1999;156:294-8.

68. Kinon BJ, Lipkovich I, Edwards SB, Adams DH, Ascher-Svanum H, Siris SG. A 24-week randomized study of olanzapine versus ziprasidone in the treatment of schizophrenia or schizoaffective disorder in patients with prominent depressive symptoms. J Clin Psychopharmacol. 2006;26:157-62.

69. Khanna P, Suo T, Komossa K, Ma H, Rummel-Kluge C, El-Sayeh HG, et al. Aripiprazole versus other atypical antipsychotics for schizophrenia. Cochrane Database Syst Rev. 2014;1:CD006569.

70. Weiden PJ, Newcomer JW, Loebel AD, Yang R, Lebovitz HE. Long-term changes in weight and plasma lipids during maintenance treatment with ziprasidone. 2008;33:985-94.

71. Alptekin K, Hafez J, Brook S, Akkaya C, Tzebelikos E, Ucok A, et al. Efficacy and tolerability of switching to ziprasidone from olanzapine, risperidone or haloperidol: an international, multicenter study. Int Clin Psychopharmacol. 2009;24:229-38.

72. Stroup TS, McEvoy JP, Ring KD, Hamer RH, LaVange LM, Swartz MS, et al. A randomized trial examining 
the effectiveness of switching from olanzapine, quetiapine, or risperidone to aripiprazole to reduce metabolic risk: comparison of antipsychotics for metabolic problems (CAMP). Am J Psychiatry [Internet]. 2011;168:947-56.

73. Keck P, Buffenstein A, Ferguson J, Feighner J, Jaffe W, Harrigan EP, et al. Ziprasidone 40 and $120 \mathrm{mg} /$ day in the acute exacerbation of schizophrenia and schizoaffective disorder: a 4-week placebo-controlled trial. Psychopharmacology. 1998;140:173-84.

74. Daniel DG, Zimbroff DL, Potkin SG, Reeves KR, Harrigan EP, Lakshminarayanan M. Ziprasidone $80 \mathrm{mg} /$ day and $160 \mathrm{mg} /$ day in the acute exacerbation of schizophrenia and schizoaffective disorder: a 6-week placebo-controlled trial. Ziprasidone Study Group. Neuropsychopharmacology. 1999;20:491-505.

75. Kane JM, Carson WH, Saha AR, McQuade RD, Ingenito GG, Zimbroff DL, et al. Efficacy and safety of aripiprazole and haloperidol versus placebo in patients with schizophrenia and schizoaffective disorder. J Clin Psychiatry. 2002;63:763-71.

76. Ahmed A, Wong RJ, Harrison SA. Nonalcoholic fatty liver disease review: diagnosis, treatment, and outcomes. Clin Gastroenterol Hepatol. 2015;13:2062-70.

77. Liu H, Lu H-Y. Nonalcoholic fatty liver disease and cardiovascular disease. World J Gastroenterol. 2014;20:8407-15.

78. Wang J, Liu Y, Zhu W, Zhang F, Zhou Z. Olanzapine-induced weight gain plays a key role in the potential cardiovascular risk: evidence from heart rate variability analysis. Sci Rep. 2014;4:7394.

79. Barber JA, Palmese L, Reutenauer EL, Grilo CM, Tek C. Implications of weight-based stigma and self-bias on quality of life among individuals with schizophrenia. J Nerv Ment Dis. 2011;199:431-5.

80. Agid O, Siu CO, Pappadopulos E, Vanderburg D, Remington G. Early prediction of clinical and functional outcome in schizophrenia. Eur Neuropsychopharmacol. 2013;23:842-51.

81. Egger C, Muehlbacher M, Schatz M, Nickel M. Influence of topiramate on olanzapine-related weight gain in women: an 18-month follow-up observation. J Clin Psychopharmacol. 2007;27:475-8.

82. De Hert M, Cohen D, Bobes J, Cetkovich-Bakmas M, Leucht S, Ndetei DM, et al. Physical illness in patients with severe mental disorders. II. Barriers to care, monitoring and treatment guidelines, plus recommendations at the system and individual level. World Psychiatry [Internet]. 2001;10:138-51.

83. Gates J, Killackey E, Phillips L, Álvarez-Jiménez M. Mental health starts with physical health: current status and future directions of non-pharmacological interventions to improve physical health in first-episode psychosis. Lancet Psychiatry. 2015;2:726-42.

84. Alvarez-Jiménez M, González-Blanch C, Vázquez-Barquero JL, Pérez-Iglesias R, Martínez-García O, Pérez-Pardal $\mathrm{T}$, et al. Attenuation of antipsychotic-induced weight gain with early behavioral intervention in drug-naive first-episode psychosis patients: a randomized controlled trial. J Clin Psychiatry. 2006;67:1253-60.

85. Alvarez-Jiménez M, Martínez-García O, Pérez-Iglesias R, Ramírez ML, Vázquez-Barquero JL, Crespo-Facorro B. Prevention of antipsychotic-induced weight gain with early behavioural intervention in first-episode psychosis: 2-year results of a randomized controlled trial. Schizophr Res. 2010;116:16-9.

86. Mukundan A, Faulkner G, Cohn T, Remington G. Antipsychotic switching for people with schizophrenia who have neuroleptic-induced weight or metabolic problems. Cochrane Database Syst Rev. 2010;CD006629.

87. Hammerman A, Dreiher J, Klang SH, Munitz H, Cohen AD, Goldfracht M. Antipsychotics and diabetes: an age-related association. Ann J Pharmacother. 2008;42:1316-22.

88. Nielsen J, Skadhede S, Correll CU. Antipsychotics associated with the development of type 2 diabetes in antipsychotic-naïve schizophrenia patients. Neuropsychopharmacology. 2010;35:1997-2004.

89. Newcomer JW, Haupt DW, Fucetola R, Melson AK, Schweiger JA, Cooper BP, et al. Abnormalities in glucose regulation during antipsychotic treatment of schizophrenia. Arch Gen Psychiatry [Internet]. 2002;59:337-45.

90. Kang SH, Lee JI. Metabolic disturbances independent of body mass in patients with schizophrenia taking atypical antipsychotics. Psychiatry Investig. 2015;12:242-8.

91. Henderson DC. Atypical antipsychotic-induced diabetes mellitus: how strong is the evidence? CNS Drugs. 2002;16:77-89.

92. Vidarsdottir S, de Leeuw van Weenen JE, Frölich M, Roelfsema F, Romijn JA, Pijl H. Effects of olanzapine and haloperidol on the metabolic status of healthy men. J Clin Endocrinol Metab. 2010;95:118-25. 
93. Rummel-Kluge C, Komossa K, Schwarz S, Hunger H, Schmid F, Lobos CA, et al. Head-to-head comparisons of metabolic side effects of second generation antipsychotics in the treatment of schizophrenia: a systematic review and meta-analysis. Schizophr Res. 2010;123:225-33.

94. Diaz FJ, Perez-Iglesias R, Mata I, Martínez-Garcia O, Vázquez-Barquero JL, de Leon $\mathrm{J}$, et al. Using structural equations to test for a direct effect of some antipsychotics on triglyceride levels in drug-naïve first-episode psychosis patients. Schizophr Res. 2011;131:82-9.

95. Birkenaes $\mathrm{AB}$, Birkeland $\mathrm{KI}$, Friis $\mathrm{S}$, Opjordsmoen $\mathrm{S}$, Andreassen OA. Hormonal markers of metabolic dysregulation in patients with severe mental disorders after olanzapine treatment under real-life conditions. J Clin Psychopharmacol. 2009;29:109-16.

96. Aston J, Rechsteiner E, Bull N, Borgwardt S, Gschwandtner U, Riecher-Rössler A. Hyperprolactinaemia in early psychosis-not only due to antipsychotics. Prog Neuropsychopharmacol Biol Psychiatry. 2010;34:1342-4.

97. Riecher-Rössler A, Rybakowski JK, Pflueger MO, Beyrau R, Kahn RS, Malik P, et al. Hyperprolactinemia in antipsychotic-naive patients with first-episode psychosis. Psychol Med. 2013;43:2571-82.

98. Pérez-Iglesias R, Mata I, Martínez-García O, Garcia-Unzueta MT, Amado JA, Valdizán EM, et al. Long-term effect of haloperidol, olanzapine, and risperidone on plasma prolactin levels in patients with first-episode psychosis. J Clin Psychopharmacol. 2012;32:804-8.

99. Garcia-Rizo C, Fernandez-Egea E, Oliveira C, Justicia A, Parellada E, Bernardo $M$, et al. Prolactin concentrations in newly diagnosed, antipsychotic-naïve patients with nonaffective psychosis. Schizophr Res. 2012;134:16-9.

100. Peuskens J, Pani L, Detraux J, De Hert M. The effects of novel and newly approved antipsychotics on serum prolactin levels: a comprehensive review. CNS Drugs. 2014;28:421-53.

101. Schooler N, Rabinowitz J, Davidson M, Emsley R, Harvey PD, Kopala L, et al. Risperidone and haloperidol in first-episode psychosis: a long-term randomized trial. Am J Psychiatry. 2005;162:947-53.

102. Zhao T, Park T-W, Yang J-C, Huang G-B, Kim M-G, Lee $\mathrm{K}-\mathrm{H}$, et al. Efficacy and safety of ziprasidone in the treatment of first-episode psychosis: an 8-week, open-label, multicenter trial. Int Clin Psychopharmacol. 2012;27:184-90.
103. Wesselmann U, Windgassen K. Galactorrhea: subjective response by schizophrenic patients. Acta Psychiatr Scand. 1995;91:152-5.

104. Byerly MJ, Marcus RN, Tran Q-V, Eudicone JM, Whitehead R, Baker RA. Effects of aripiprazole on prolactin levels in subjects with schizophrenia during cross-titration with risperidone or olanzapine: analysis of a randomized, open-label study. Schizophr Res. 2009;107:218-22.

105. Ziadi Trives M, Bonete Llácer J-M, García Escudero M-A, Martínez Pastor CJ. Effect of the addition of aripiprazole on hyperprolactinemia associated with risperidone long-acting injection. J Clin Psychopharmacol. 2013;33:538-41.

106. Voicu V, Medvedovici A, Ranetti AE, Rădulescu FŞ. Drug-induced hypo- and hyperprolactinemia: mechanisms, clinical and therapeutic consequences. Expert Opin Drug Metab Toxicol. 2013;9:955-68.

107. Correll CU, Penzner JB, Parikh UH, Mughal T, Javed $\mathrm{T}$, Carbon $\mathrm{M}$, et al. Recognizing and monitoring adverse events of second-generation antipsychotics in children and adolescents. Child Adolesc Psychiatr Clin N Am. 2006;15:177-206.

108. Toren P, Ratner S, Laor N, Weizman A. Benefit-risk assessment of atypical antipsychotics in the treatment of schizophrenia and comorbid disorders in children and adolescents. Drug Saf. 2004;27:1135-56.

109. Perkins DO. Predictors of noncompliance in patients with schizophrenia. J Clin Psychiatry. 2002;63:1121-8.

110. Young SL, Taylor M, Lawrie SM. "First do no harm". A systematic review of the prevalence and management of antipsychotic adverse effects. J Psychopharmacol. 2014;29:353-62.

111. Leucht S, Cipriani A, Spineli L, Mavridis D, Orey D, Richter F, et al. Comparative efficacy and tolerability of 15 antipsychotic drugs in schizophrenia: a multiple-treatments meta-analysis. Lancet. 2013;382:951-62.

112. Chatterjee A, Chakos M, Koreen A, Geisler S, Sheitman B, Woerner M, et al. Prevalence and clinical correlates of extrapyramidal signs and spontaneous dyskinesia in never-medicated schizophrenic patients. Am J Psychiatry. 1995;152:1724-9.

113. Basson BR, Kinon BJ, Taylor CC, Szymanski KA, Gilmore JA, Tollefson GD. Factors influencing acute weight change in patients with schizophrenia treated with olanzapine, haloperidol, or risperidone. J Clin Psychiatry. 2001;62:231-8. 
114. Liu X, De Haan S. Chlorpromazine dose for people with schizophrenia. Cochrane Database Syst Rev. 2009.

115. Leucht S, Samara M, Heres S, Patel MX, Woods SW, Davis JM. Dose equivalents for second-generation antipsychotics: the minimum effective dose method. Schizophr Bull. 2014;40:314-26.

116. Buchanan RW, Kreyenbuhl J, Kelly DL, Noel JM, Boggs DL, Fischer BA, et al. The schizophrenia PORT psychopharmacological treatment recommendations and summary statements. Schizophr Bull. 2009;2010(36):71-93.

117. Gardner DM, Murphy AL, O'Donnell H, Centorrino F, Baldessarini RJ. International consensus study of antipsychotic dosing. Am J Psychiatry. 2010;167:686-93.

118. Emsley RA. Risperidone in the treatment of first-episode psychotic patients: a double-blind multicenter study. Risperidone Working Group. Schizophr Bull. 1999;25:721-9.

119. Robinson DG, Woerner MG, Napolitano B, Patel RC, Sevy SM, Gunduz-Bruce H, et al. Randomized comparison of olanzapine versus risperidone for the treatment of first-episode schizophrenia: 4-month outcomes. Am J Psychiatry. 2006;163:2096-102.

120. Lieberman JA, Tollefson G, Tohen M, Green AI, Gur $\mathrm{RE}$, Kahn R, et al. Comparative efficacy and safety of atypical and conventional antipsychotic drugs in first-episode psychosis: a randomized, double-blind trial of olanzapine versus haloperidol. Am J Psychiatry. 2003;160:1396-404.

121. Oosthuizen P, Emsley RA, Turner J, Keyter N. Determining the optimal dose of haloperidol in first-episode psychosis. J Psychopharmacol. 2001;15:251-5.

122. Seeman P. All roads to schizophrenia lead to dopamine supersensitivity and elevated dopamine D2 high receptors. CNS Neurosci Ther. 2011;17:118-32.

123. Leucht S, Tardy M, Komossa K, Heres S, Kissling W, Davis JM. Maintenance treatment with antipsychotic drugs for schizophrenia. Cochrane Database Syst Rev. 2012; CD008016.

124. Lehman AF, Lieberman JA, Dixon LB, McGlashan TH, Miller AL, Perkins DO, et al. Practice guideline for the treatment of patients with schizophrenia, second edition. Am J Psychiatry. 2004;161:1-56.

125. National Institute for Health and Care Excellence (NICE). Psychosis and schizophrenia in adults: treatment and management: NICE Clinical
Guideline 178. London: National Institute for Health and Care Excellence; 2014. p. 685.

126. Chue P, Stip E, Remington G, Kopala L. Switching atypical antipsychotics: a review. Acta Neuropsychiatr. 2004;16:301-13.

127. Samara MT, Leucht C, Leeflang MM, Anghelescu I-G, Chung Y-C, Crespo-Facorro B, et al. Early improvement as a predictor of later response to antipsychotics in schizophrenia: a diagnostic test review. Am J Psychiatry. 2015;172:617-29.

128. Agid O, Arenovich T, Sajeev G, Zipursky RB, Kapur $\mathrm{S}$, Foussias G, et al. An algorithm-based approach to first-episode schizophrenia: response rates over 3 prospective antipsychotic trials with a retrospective data analysis. J Clin Psychiatry. 2011;72:1439-44.

129. Gardos G. Are antipsychotic drugs interchangeable? J Nerv Ment Dis. 1974;159:343-8.

130. Essock SM, Covell NH, Davis SM, Stroup TS, Rosenheck RA, Lieberman JA. Effectiveness of switching antipsychotic medications. Am J Psychiatry. 2006;163:2090-5.

131. Hugenholtz GW, Heerdink ER, Meijer WE, Stolker J-J, Egberts AC, Nolen WA. Reasons for switching between antipsychotics in daily clinical practice. Pharmacopsychiatry. 2005;38:122-4.

132. Newcomer JW, Weiden PJ, Buchanan RW. Switching antipsychotic medications to reduce adverse event burden in schizophrenia: establishing evidence-based practice. J Clin Psychiatry. 2013;74:1108-20.

133. Ganguli R. Rationale and strategies for switching antipsychotics. Am J Health Syst Pharm. 2002;59:S22-6.

134. Bernardo M, Vieta E, Saiz Ruiz J, Rico-Villademoros $\mathrm{F}$, Alamo C, Bobes J, et al. Recommendations for switching antipsychotics. A position statement of the Spanish Society of Psychiatry and the Spanish Society of Biological Psychiatry. Rev Psiquiatr Salud Ment. 2011;4:150-68.

135. Gallego JA, Bonetti J, Zhang J, Kane JM, Correll CU. Prevalence and correlates of antipsychotic polypharmacy: a systematic review and meta-regression of global and regional trends from the 1970 s to 2009 . Schizophr Res. 2012;138:18-28.

136. Perry Y, Murrihy RC, Varlow M, Dedousis-Wallace A, Ellis DM, Langdon R, et al. The development and implementation of a pilot CBT for early psychosis service: achievements and challenges. Early Interv Psychiatry. 2015;9:252-9. 
137. Barrowclough C, Marshall M, Gregg L, Fitzsimmons $\mathrm{M}$, Tomenson B, Warburton J, et al. A phase-specific psychological therapy for people with problematic cannabis use following a first episode of psychosis: a randomized controlled trial. Psychol Med. 2014;44:2749-61.

138. Thornicroft G, Susser E. Evidence-based psychotherapeutic interventions in the community care of schizophrenia. Br J Psychiatry. 2001;178:2-4.

139. Pilling S, Bebbington P, Kuipers E, Garety P, Geddes J, Orbach G, et al. Psychological treatments in schizophrenia: I. Meta-analysis of family intervention and cognitive behaviour therapy. Psychol Med. 2002;32:763-82.

140. Jones C, Cormac I, Silveira da Mota Neto JI, Campbell C. Cognitive behaviour therapy for schizophrenia. Cochrane Database Syst Rev. 2004;CD000524.

141. Pfammatter M, Junghan UM, Brenner HD. Efficacy of psychological therapy in schizophrenia: conclusions from meta-analyses. Schizophr Bull. 2006;32(Suppl 1):S64-80.

142. Lewis SW, Barnes TRE, Davies L, Murray RM, Dunn G, Hayhurst KP, et al. Randomized controlled trial of effect of prescription of clozapine versus other second-generation antipsychotic drugs in resistant schizophrenia. Schizophr Bull. 2006;32:715-23.

143. Turkington D, Kingdon D, Turner T. Effectiveness of a brief cognitive-behavioural therapy intervention in the treatment of schizophrenia. Br J Psychiatry. 2002;180:523-7.

144. Wiersma D, Jenner JA, Nienhuis FJ, van de Willige G. Hallucination focused integrative treatment improves quality of life in schizophrenia patients. Acta Psychiatr Scand. 2004;109:194-201.

145. Wykes T, Hayward P, Thomas N, Green N, Surguladze S, Fannon D, et al. What are the effects of group cognitive behaviour therapy for voices? A randomised control trial. Schizophr Res. 2005;77:201-10.

146. Jauhar S, McKenna PJ, Radua J, Fung E, Salvador R, Laws KR. Cognitive-behavioural therapy for the symptoms of schizophrenia: systematic review and meta-analysis with examination of potential bias. Br J Psychiatry. 2014;204:20-9.

147. Wykes T, Steel C, Everitt B, Tarrier N. Cognitive behavior therapy for schizophrenia: effect sizes, clinical models, and methodological rigor. Schizophr Bull. 2008;34:523-37.
148. Barrowclough C, Haddock G, Wykes T, Beardmore $\mathrm{R}$, Conrod P, Craig T, et al. Integrated motivational interviewing and cognitive behavioural therapy for people with psychosis and comorbid substance misuse: randomised controlled trial. BMJ. 2010;341:c6325.

149. Marshall M, Rathbone J. Early intervention for psychosis. Cochrane Database Syst Rev. 2006;CD004718.

150. Hjorthoj CR, Baker A, Fohlmann A, Nordentoft M. Intervention efficacy in trials targeting cannabis use disorders in patients with comorbid psychosis systematic review and meta-analysis. Curr Pharm Des. 2014;20:2205-11.

151. Marshall M, Barrowclough C, Drake R, Husain N, Lobban $\mathrm{F}$, Lovell $\mathrm{K}$, et al. The HELPER programme: HEalthy Living and Prevention of Early Relapsethree exploratory randomised controlled trials of phase-specific intervention. Southampton: NIHR Journals Library. Programme Grants for Applied Research; 2015.

152. Wykes T. Cognitive-behaviour therapy and schizophrenia. Evid Based Ment Health. 2014;17:67-8.

153. Robinson D, Woerner MG, Alvir JMJ, Bilder R, Goldman R, Geisler S, et al. Predictors of relapse following response from a first episode of schizophrenia or schizoaffective disorder. Arch Gen Psychiatry. 1999;56:241.

154. Coldham EL, Addington J, Addington D. Medication adherence of individuals with a first episode of psychosis. Acta Psychiatr Scand. 2002;106:286-90.

155. Caseiro O, Pérez-Iglesias R, Mata I, Martínez-Garcia $\mathrm{O}$, Pelayo-Terán JM, Tabares-Seisdedos R, et al. Predicting relapse after a first episode of non-affective psychosis: a three-year follow-up study. J Psychiatr Res. 2012;46:1099-105.

156. Wunderink L, Nienhuis FJ, Sytema S, Slooff CJ, Knegtering R, Wiersma D. Guided discontinuation versus maintenance treatment in remitted first-episode psychosis: relapse rates and functional outcome. J Clin Psychiatry. 2007;68:654-61.

157. Wunderink L, Nieboer RM, Wiersma D, Sytema S, Nienhuis FJ. Recovery in remitted first-episode psychosis at 7 years of follow-up of an early dose reduction/discontinuation or maintenance treatment strategy: long-term follow-up of a 2-year randomized clinical trial. JAMA Psychiatry. 2013;70:913-20.

158. Wunderink L, Sytema S. Early medication discontinuation on long-term recovery outcome in 
first-episode psychosis-reply. JAMA Psychiatry. 2014;71:208-9.

159. Zipursky RB, Menezes NM, Streiner DL. Risk of symptom recurrence with medication discontinuation in first-episode psychosis: a systematic review. Schizophr Res. 2014;152:408-14.

160. De Hert M, Sermon J, Geerts P, Vansteelandt K, Peuskens J, Detraux J. The use of continuous treatment versus placebo or intermittent treatment strategies in stabilized patients with schizophrenia: a systematic review and meta-analysis of randomized controlled trials with first- and second-generation antipsychotics. CNS Drugs. 2015;29:637-58.

161. Alvarez-Jimenez M, Priede A, Hetrick SE, Bendall S, Killackey E, Parker AG, et al. Risk factors for relapse following treatment for first episode psychosis: a systematic review and meta-analysis of longitudinal studies. Schizophr Res. 2012;139:116-28.

162. Haddad PM, Brain C, Scott J. Nonadherence with antipsychotic medication in schizophrenia: challenges and management strategies. Patient Relat Outcome Meas. 2014;5:43-62.

163. Álvarez-Jiménez M, Parker AG, Hetrick SE, McGorry PD, Gleeson JF. Preventing the second episode: a systematic review and meta-analysis of psychosocial and pharmacological trials in first-episode psychosis. Schizophr Bull. 2011; 619-630.

164. Heres S, Lambert M, Vauth R. Treatment of early episode in patients with schizophrenia: the role of long acting antipsychotics. Eur Psychiatry. 2014;29(Suppl 2):1409-13.

165. Rauch AS, Fleischhacker WW. Long-acting injectable formulations of new-generation antipsychotics: a review from a clinical perspective. CNS Drugs. 2013;637-652.

166. Kirschner M, Theodoridou A, Fusar-Poli P, Kaiser S, Jäger M. Patients' and clinicians' attitude towards long-acting depot antipsychotics in subjects with a first episode of psychosis. Ther Adv Psychopharmacol. 2013;3:89-99.

167. Weiden PJ, Schooler NR, Weedon JC, Elmouchtari A, Sunakawa A, Goldfinger SM. A randomized controlled trial of long-acting injectable risperidone vs continuation on oral atypical antipsychotics for first-episode schizophrenia patients: initial adherence outcome. J Clin Psychiatry. 2009;70:1397-406.

168. Weiden PJ, Schooler NR, Weedon JC, Elmouchtari A, Sunakawa-McMillan A. Maintenance treatment with long-acting injectable risperidone in first-episode schizophrenia: a randomized effectiveness study. J Clin Psychiatry. 2012;73:1224-33.

169. Samalin L, Charpeaud T, Blanc O, Heres S, Llorca P-M. Clinicians' attitudes toward the use of long-acting injectable antipsychotics. J Nerv Ment Dis. 2013;201:553-9.

170. Taylor M, Ng KYB. Should long-acting (depot) antipsychotics be used in early schizophrenia? A systematic review. Aust N Z J Psychiatry. 2013;47:624-30.

171. Hamann J, Lipp M-L, Christ-Zapp S, Spellmann I, Kissling W. Psychiatrist and patient responses to suspected medication nonadherence in schizophrenia spectrum disorders. Psychiatr Serv. 2014;65:881-7.

172. Andreasen NC, Carpenter WT, Kane JM, Lasser RA, Marder SR, Weinberger DR. Remission in schizophrenia: proposed criteria and rationale for consensus. Am J Psychiatry. 2005;162:441-9.

173. AlAqeel B, Margolese HC. Remission in schizophrenia: critical and systematic review. Harv Rev Psychiatry. 2012;20:281-97.

174. Díaz I, Pelayo-Terán JM, Pérez-Iglesias R, Mata I, Tabarés-Seisdedos R, Suárez-Pinilla $\mathrm{P}$, et al. Predictors of clinical remission following a first episode of non-affective psychosis: sociodemographics, premorbid and clinical variables. Psychiatry Res. 2013;206:181-7.

175. Marshall M, Rathbone J. Early intervention for psychosis. Schizophr Bull. 2011;37:1111-4.

176. Jansen JE, Gleeson J, Cotton S. Towards a better understanding of caregiver distress in early psychosis: a systematic review of the psychological factors involved. Clin Psychol Rev. 2015;35:56-66.

177. Yesufu-Udechuku A, Harrison B, Mayo-Wilson E, Young N, Woodhams P, Shiers D, et al. Interventions to improve the experience of caring for people with severe mental illness: systematic review and meta-analysis. $\mathrm{Br} \mathrm{J}$ Psychiatry. 2015;206:268-74.

178. Zajdel P, Partyka A, Marciniec K, Bojarski AJ, Pawlowski M, Wesolowska A. Quinoline- and isoquinoline-sulfonamide analogs of aripiprazole: novel antipsychotic agents? Fut Med Chem. 2014;6:57-75.

179. Citrome L, Ota A, Nagamizu K, Perry P, Weiller E, Baker RA. The effect of brexpiprazole (OPC-34712) and aripiprazole in adult patients with acute schizophrenia: results from a randomized, exploratory study. Int Clin Psychopharmacol. 2016;31:192-201. 
180. Debelle M, Németh G, Szalai E, Szatmári B, Harsányi J, Barabassy A, et al. P.3.d.053 Cariprazine as monotherapy for the treatment of schizophrenia patients with predominant negative symptoms: a double-blind, active controlled trial. Eur Neuropsychopharmacol. 2015;25:S510.

181. Nakamura T, Kubota T, Iwakaji A, Imada M, Kapás M, Morio Y. Clinical pharmacology study of cariprazine (MP-214) in patients with schizophrenia (12-week treatment). Drug Des Dev Ther. 2016;10:327-38.

182. Citrome L, Durgam S, Lu K, Ferguson P, Laszlovszky I. The effect of cariprazine on hostility associated with schizophrenia: post hoc analyses from 3 randomized controlled trials. J Clin Psychiatry. 2016;77:109-15.

183. Kalkman HO, Subramanian N, Hoyer D. Extended radioligand binding profile of iloperidone: a broad spectrum dopamine/serotonin/norepinephrine receptor antagonist for the management of psychotic disorders. Neuropsychopharmacology. 2001;25:904-14.

184. Weiden PJ. Iloperidone for the treatment of schizophrenia: an updated clinical review. Clin Schizophr Relat Psychoses. 2012;6:34-44.

185. Meltzer HY, Massey BW. The role of serotonin receptors in the action of atypical antipsychotic drugs. Curr Opin Pharmacol. 2011;11:59-67.

186. De Hert M, Yu W, Detraux J, Sweers K, van Winkel $\mathrm{R}$, Correll CU. Body weight and metabolic adverse effects of asenapine, iloperidone, lurasidone and paliperidone in the treatment of schizophrenia and bipolar disorder: a systematic review and exploratory meta-analysis. CNS Drugs. 2012;26:733-59. 